\title{
www.czasopisma.pan.pl \\ Pressing Speed, Specific Pressure and Mechanical Properties of Aluminium Cast
}

\author{
S. Gaspar*, J. Pasko \\ Department of Design Technical Systems, Faculty of Manufacturing Technologies in Presov, \\ Technical University of Kosice, Bayerova 1, 08-001 Presov, Slovak Republic \\ *Corresponding author. E-mail address: stefan.gaspar@tuke.sk
}

Received 05.04.2016; accepted in revised form 03.05.2013

\begin{abstract}
Recent research in the process of aluminum alloy die castings production, which is nowadays deeply implemented into the rapidly growing automobile, shipping and aircraft industries, is aimed at increasing the useful qualitative properties of the die casting in order to obtain its high mechanical properties at acceptable economic cost. Problem of technological factors of high pressure die casting has been a subject of worldwide research (EU, US, Japan, etc.). The final performance properties of die castings are subjected to a large number of technological factors. The main technological factors of high pressure die casting are as follows: plunger pressing speed, specific (increase) pressure, mold temperature as well as alloy temperature. The contribution discusses the impact of the plunger pressing speed and specific (increase) pressure on the mechanical properties of the casting aluminum alloy.
\end{abstract}

Keywords: Die casting, Plunger pressing speed, Specific pressure, Mechanical properties

\section{Introduction}

Current consumption of aluminium alloys constantly grows due to demands in sectors of electrotechnical, aviation, and automotive industries. At present the automotive industry is pushed by the European acts on environment into a blind alley implementing emission limits, being continually made stricter, issued by driving units of automobiles and thus rightful seems the utilization of light aluminium and of other non-ferrous alloys for weight saving with maintenance of safety and technical facilities.[1] The pressure to reduce the costs represents the chief criterion necessary to assure the operation of companies and therefore new competitive and reliable materials and technologies at affordable price are inevitable to be introduced into production. Requirements and demands of castings made of light alloys are increasing and shall be increasing further on. As it has been already mentioned unceasingly growing demand for aluminium alloys is also connected with the issue of global warming and related problem of $\mathrm{CO}_{2}$ release into the atmosphere. Connection between alloys and $\mathrm{CO}_{2}$ emissions is logical as, for instance, automobile weight saving shall be directly reflected in decrease of $\mathrm{CO}_{2}$ emissions. Clear instance is the fact that automobile weight saving equal to $100 \mathrm{~kg}$ is equivalent to reduction of produced $\mathrm{CO}_{2}$ by $9 \mathrm{~g}$ per $\mathrm{km}$. As well as production of aluminium alloys the technologies, by means of which alloys are machined, shall get the green light in automotive industry and shall develop in the future. $[1,2]$

\section{Characteristic of die casting}

Die casting technology is an ideal method for the production of aluminium casts in large quantities with high labour productivity. The principle of this technology consists in the 
molding of a liquid alloy into a metal mold cavity at a high speed $\left(10-100 \mathrm{~m} \times \mathrm{s}^{-1}\right)$ using high pressure $(2-250 \mathrm{MPa})$. Using this method of casting it is possible to manufacture geometrically complex casts with the thickness of their walls smaller than $2 \mathrm{~mm}$ and with the accuracy of $0.3-0.5 \%$. [2, 3]

The basic technological parameters of die casting include: plunger pressing speed, specific (increase) pressure, temperature of cast alloy, temperature of mold and temperature of pressing chamber. [1]

\section{Plunger pressing speed and specific pressure}

Pressing plunger speed must be adjustable in a wide range whereby the required maximum speeds. Pressing speed of a plunger is a determining factor in the mode of a mold cavity filling. It is influential for metal speed in the gating system and in the ingate. Speed of the alloy flow in the ingate affects mechanical properties of the casting and thus acts on the internal and surface quality of die castings. Selection of the right speed of a mold cavity filling depends on factors such as the alloy type, the casting complexity, the casting wall thickness and the ratio of the ingate area to the casting area. Depending on determination of these factors the speed in the ingate varies from 0,6 to $100 \mathrm{~m} \times \mathrm{s}^{-1}$. $[2,4]$

It is important to determine the optimal value of such speed, e.g. its increase above the optimal value recorded a strength decrease due to adhering of the alloy in the ingate. This can be explained by the fact that increasing the alloy flow speed caused a gradual washing off the initially formed crust on a mold wall. A further speed increase in the ingate can completely wash off the crust and the parallel of dry friction occurs between the alloy flow and a mold material. As a result, there is a rapid temperature increase on the surface of a mold cavity and an accelerated diffusion of the alloy element into the hot mold surface. After solidification it is manifested as intense adhering of the alloy in the ingate areas. $[4,5]$

The value of the hydrodynamic pressure on the metal in the filling chamber has to be such that the mold cavity is filled at a suitable rate i.e. at the optimum time. Effect of the hydrodynamic pressure on the metal in the filling chamber is significantly manifested at the time of the mold filling. The progress of the hydrodynamic pressure on the metal in the filling chamber varies according to the method of filling. In order to overcome the resistance of the solidified melt in thin cross-sections of the mold cavity as well as the gas resistance in the mold cavity, the so called specific (increase) pressure (high hydrostatic pressure) is required. The pressure uploads from the pressing plunger via the intake channel. The later the inlet channel solidifies, the longer the action of pressure is. The process of hydrostatic pressure transfer into the mold cavity is called the specific (increase) pressure. The main task of the specific pressure consists in replacing the gravity substitution melt into the empty cavities of the die casting thus minimising the expansion of the gas bubbles during crystallization. [1,9]

\section{Characteristics of observed factors}

Within the experimental research, the quality of the die casting was represented by the permanent deformation "s". During the experiment implementation, constant and variable technological factors, the influence of which has been studied, were determined. They are as follows:

Technological factors which were constant:

- liquid alloy temperature:

$705^{\circ} \mathrm{C} \pm 5^{\circ} \mathrm{C}$

- mold temperature:

- diameter of pressing chamber:

$200{ }^{\circ} \mathrm{C} \pm 5^{\circ} \mathrm{C}$

$70 \mathrm{~mm}$

Technological factors which were variable:

- plunger speed: 2,$0 ; 2,2 ; 2,4 ; 2,6 ; 2,8 ; 3,0 ; 3,2\left[\mathrm{~m} \times \mathrm{s}^{-1}\right]$

- specific pressure: $13 ; 15 ; 18 ; 22 ; 25[\mathrm{MPa}]$

\section{Experimental material}

The effect the plunger pressing speed and specific pressure on permanent deformation values was verified using experimental samples (Fig. 1) casted on the die casting machine "Müller Weingarten 600", which is the machine with a horizontal cold chamber. The experimental samples were made of aluminum alloy EN AC 47100. Chemical composition complies with the EN 1706 standard and is being indicated in the Table 1.

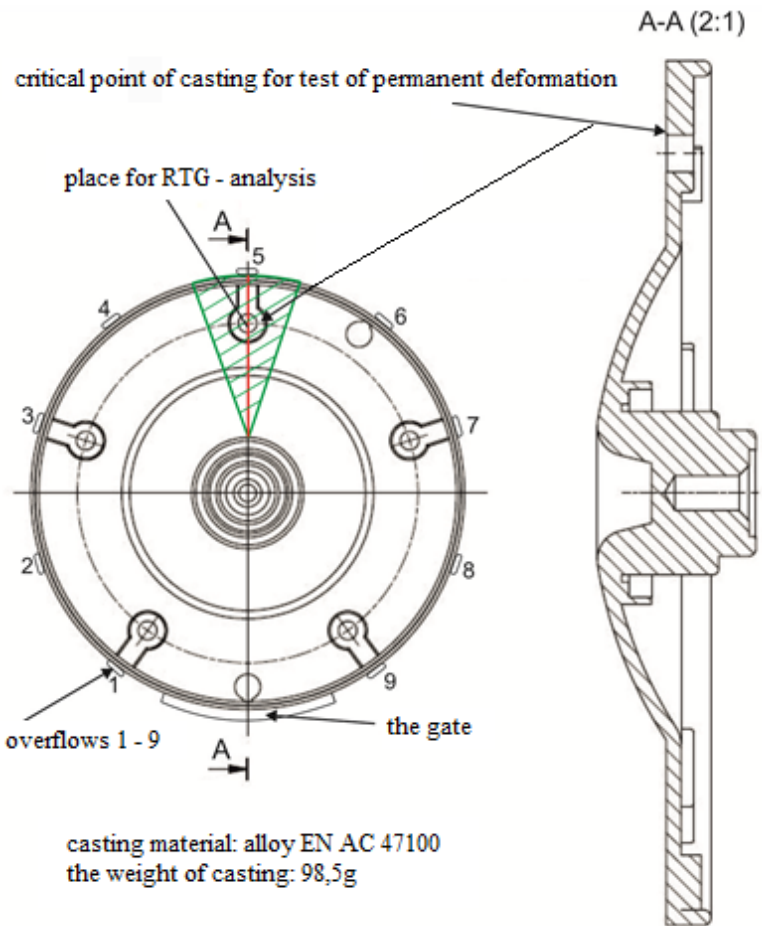

Fig. 1. Experimental sample - flange of alternator 
Table 1.

Chemical composition of experimental alloy / \% content of elements /

\begin{tabular}{|c|c|c|c|c|c|c|c|c|c|c|c|}
\hline $\mathrm{Al}$ & $\mathrm{Si}$ & $\mathrm{Fe}$ & $\mathrm{Cu}$ & $\mathrm{Mn}$ & $\mathrm{Mg}$ & $\mathrm{Cr}$ & $\mathrm{Ni}$ & $\mathrm{Zn}$ & $\mathrm{Pb}$ & $\mathrm{Sn}$ & $\mathrm{Ti}$ \\
\hline 85,27 & 12,02 & 0,71 & 1,19 & 0,21 & 0,13 & 0,02 & 0,02 & 0,35 & 0,02 & 0,03 & 0,03 \\
\hline \multicolumn{12}{|c|}{ according to EN 1706} \\
\hline the rest & $\begin{array}{l}10,5- \\
13,5\end{array}$ & $\begin{array}{c}\max . \\
1,5\end{array}$ & $0,7-1,2$ & $\begin{array}{c}\max . \\
0,35\end{array}$ & $\begin{array}{l}\max \text {. } \\
0,35\end{array}$ & $\begin{array}{c}\max . \\
0,1\end{array}$ & $\begin{array}{c}\max . \\
0,3\end{array}$ & $\begin{array}{c}\max . \\
0,55\end{array}$ & $\begin{array}{c}\max . \\
0,2\end{array}$ & $\begin{array}{c}\max . \\
0,1\end{array}$ & 0,2 \\
\hline
\end{tabular}

\section{Evaluation of permanent deformation}

Permanent deformation tests were carried out on the device TIRAtest 28200 at the critical point of the die casting. The tests were conducted under the established standards GME 60156 and GME 06007. The critical point of the die casting is characterized as the test specimen and based on its geometric characteristics the initial load force $\mathrm{Fa}=16 \mathrm{kN}$ and loading speed $0,01 \mathrm{~m} \times \mathrm{s}^{-1}$ were established. The following load discharge of the half of the initial force $\mathrm{Fm}=8 \mathrm{kN}$ (in terms of the standards $[10,11]$ ) has been observed at the maximum value of permanent deformation.

As defined in $[10,11]$, the permanent deformation at $50 \%$ load $\mathrm{Fa}$ has a value of $0.150 \mathrm{~mm}$. The software of the test equipment has recorded and subsequently evaluated the permanent deformation tests when the plunger pressing speed and the specific pressure were changed. The results of the tests are presented in Table 2 and Table 3. The graph of permanent deformation tests dependent on a change of the plunger pressing speed and the specific pressure is shown in Figure 2 and Figure 3.

Table 2.

Permanent deformation test dependent on a change of plunger pressing speed

\begin{tabular}{|c|c|c|c|c|c|c|c|c|c|}
\hline $\begin{array}{c}\text { Sample } \\
\text { No. }\end{array}$ & $\begin{array}{c}\text { Plunger } \\
\text { speed } \\
{\left[\mathrm{m} \times \mathrm{s}^{-1}\right]}\end{array}$ & $\begin{array}{c}\text { Specific } \\
\text { pressure } \\
{[\mathrm{MPa}]}\end{array}$ & Perman & $\begin{array}{l}\text { deformation } s \\
\text { am] } \\
\text { Arithmetic } \\
\quad \text { mean }\end{array}$ & $\begin{array}{c}\text { Sample } \\
\text { No. }\end{array}$ & 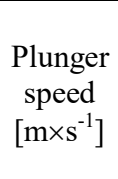 & $\begin{array}{c}\text { Specific } \\
\text { pressure } \\
{[\mathrm{MPa}]}\end{array}$ & Perman & $\begin{array}{l}\text { leformation } s \\
\text { Arithmetic } \\
\quad \text { mean }\end{array}$ \\
\hline A 1.1 & \multirow{5}{*}{2,0} & \multirow{5}{*}{25} & 0,079 & \multirow{5}{*}{0,068} & A 5.1 & \multirow{5}{*}{2,8} & \multirow{5}{*}{25} & 0,031 & \\
\hline A 1.2 & & & 0,064 & & A 5.2 & & & 0,036 & \\
\hline A 1.3 & & & 0,061 & & A 5.3 & & & 0,033 & $\mathbf{0 , 0 3 3}$ \\
\hline A 1.4 & & & 0,069 & & A 5.4 & & & 0,030 & \\
\hline A 1.5 & & & 0,068 & & A 5.5 & & & 0,034 & \\
\hline A 2.1 & \multirow{5}{*}{2,2} & \multirow{5}{*}{25} & 0,045 & \multirow{5}{*}{0,055} & A 6.1 & \multirow{5}{*}{3,0} & \multirow{5}{*}{25} & 0,036 & \\
\hline A 2.2 & & & 0,059 & & A 6.2 & & & 0,037 & \\
\hline A 2.3 & & & 0,056 & & A 6.3 & & & 0,033 & 0,035 \\
\hline A 2.4 & & & 0,061 & & A 6.4 & & & 0,038 & \\
\hline A 2.5 & & & 0,054 & & A 6.5 & & & 0,031 & \\
\hline A 3.1 & \multirow{5}{*}{2,4} & \multirow{5}{*}{25} & 0,043 & \multirow{5}{*}{0,044} & A 7.1 & \multirow{5}{*}{3,2} & \multirow{5}{*}{25} & 0,053 & \\
\hline A 3.2 & & & 0,040 & & A 7.2 & & & 0,057 & \\
\hline A 3.3 & & & 0,049 & & A 7.3 & & & 0,046 & 0,052 \\
\hline A 3.4 & & & 0,041 & & A 7.4 & & & 0,048 & \\
\hline A 3.5 & & & 0,047 & & A 7.5 & & & 0,054 & \\
\hline A 4.1 & \multirow{5}{*}{2,6} & \multirow{5}{*}{25} & 0,035 & \multirow{5}{*}{$\mathbf{0 , 0 3 7}$} & & & & & \\
\hline A 4.2 & & & 0,042 & & & & & & \\
\hline A 4.3 & & & 0,035 & & & & & & \\
\hline A 4.4 & & & 0,041 & & & & & & \\
\hline A 4.5 & & & 0,034 & & & & & & \\
\hline
\end{tabular}


Table 3.

Permanent deformation test dependent on a change of specific pressure

\begin{tabular}{|c|c|c|c|c|c|c|c|c|c|}
\hline $\begin{array}{c}\text { Sample } \\
\text { No. }\end{array}$ & $\begin{array}{c}\text { Specific } \\
\text { pressure } \\
{[\mathrm{MPa}]}\end{array}$ & $\begin{array}{c}\text { Plunger } \\
\text { speed } \\
{\left[\mathrm{m} \times \mathrm{s}^{-1}\right]}\end{array}$ & Perman & $\begin{array}{l}\text { leformation } s \\
\text { Im] } \\
\text { Arithmetic } \\
\quad \text { mean }\end{array}$ & $\begin{array}{c}\text { Sample } \\
\text { No. }\end{array}$ & $\begin{array}{c}\text { Specific } \\
\text { pressure } \\
{[\mathrm{MPa}]}\end{array}$ & 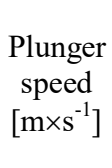 & Permane & $\begin{array}{l}\text { eformation } s \\
\text { m] } \\
\text { Arithmetic } \\
\quad \text { mean }\end{array}$ \\
\hline B 1.1 & \multirow{5}{*}{13} & \multirow{5}{*}{2,6} & 0,094 & \multirow{5}{*}{0,089} & B 4.1 & \multirow{5}{*}{22} & \multirow{5}{*}{2,6} & 0,037 & \\
\hline B 1.2 & & & 0,088 & & B 4.2 & & & 0,040 & \\
\hline B 1.3 & & & 0,090 & & B 4.3 & & & 0,043 & 0,041 \\
\hline B 1.4 & & & 0,081 & & B 4.4 & & & 0,045 & \\
\hline B 1.5 & & & 0,093 & & B 4.5 & & & 0,042 & \\
\hline B 2.1 & \multirow{5}{*}{15} & \multirow{5}{*}{2,6} & 0,076 & \multirow{5}{*}{0,072} & B 5.1 & \multirow{5}{*}{25} & \multirow{5}{*}{2,6} & 0,035 & \\
\hline B 2.2 & & & 0,068 & & B 5.2 & & & 0,042 & \\
\hline B 2.3 & & & 0,069 & & В 5.3 & & & 0,035 & $\mathbf{0 , 0 3 7}$ \\
\hline В 2.4 & & & 0,065 & & B 5.4 & & & 0,041 & \\
\hline B 2.5 & & & 0,081 & & B 5.5 & & & 0,034 & \\
\hline B 3.1 & \multirow{5}{*}{18} & \multirow{5}{*}{2,6} & 0,059 & \multirow{5}{*}{0,054} & & & & & \\
\hline B 3.2 & & & 0,052 & & & & & & \\
\hline B 3.3 & & & 0,055 & & & & & & \\
\hline B 3.4 & & & 0,048 & & & & & & \\
\hline B 3.5 & & & 0,054 & & & & & & \\
\hline
\end{tabular}

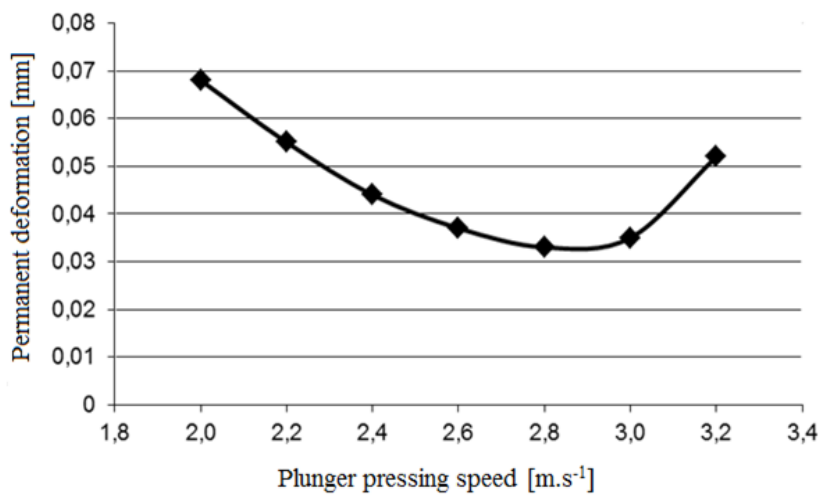

Fig. 2. Dependence of average values of permanent deformation on the change of plunger pressing speed

\section{RTG - analysis}

Internal homogeneity of castings was performed with the selected castings at the points of permanent deformation measurements to allow comparison of the achieved results of permanent deformation with the RTG pictures. Fig. 4 documents the RTG picture without any obvious internal defects of the analysed sample No. B 5.3 which was included into a set of samples showing the lowest values of the permanent deformation.

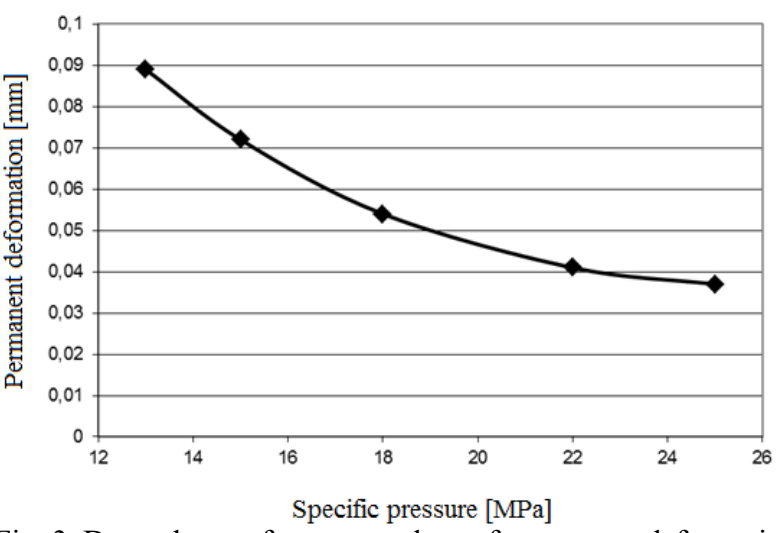

Fig. 3. Dependence of average values of permanent deformation on the change of specific pressure

The RTG picture of the analysed sample No. B 1.4 (Fig. 5) shows obvious internal defects documented by light spots. The presented samples were included into a set of samples showing the highest values of permanent deformation. 


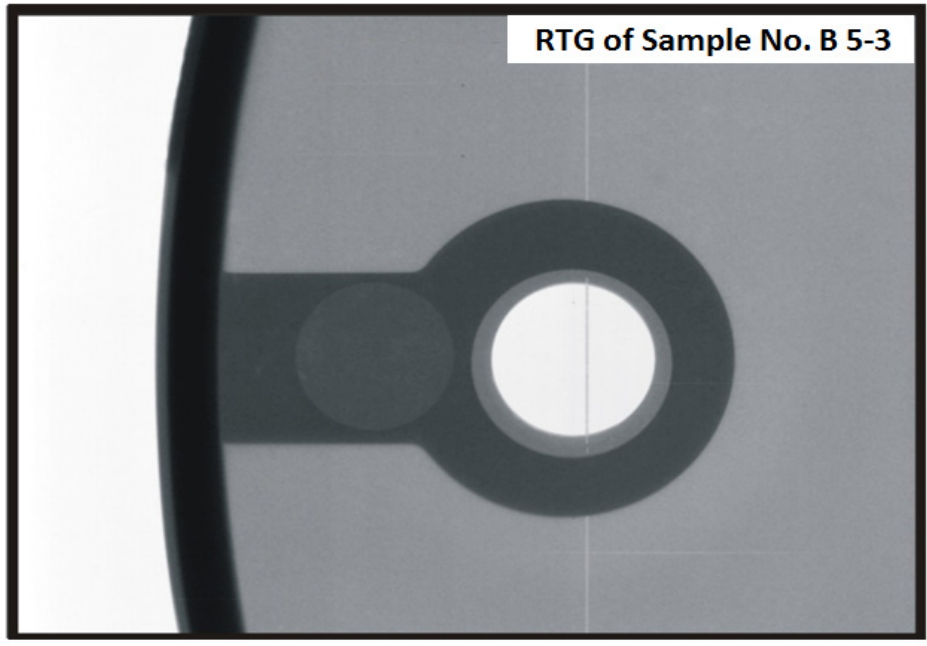

Fig. 4. RTG picture of sample No. B 5.3

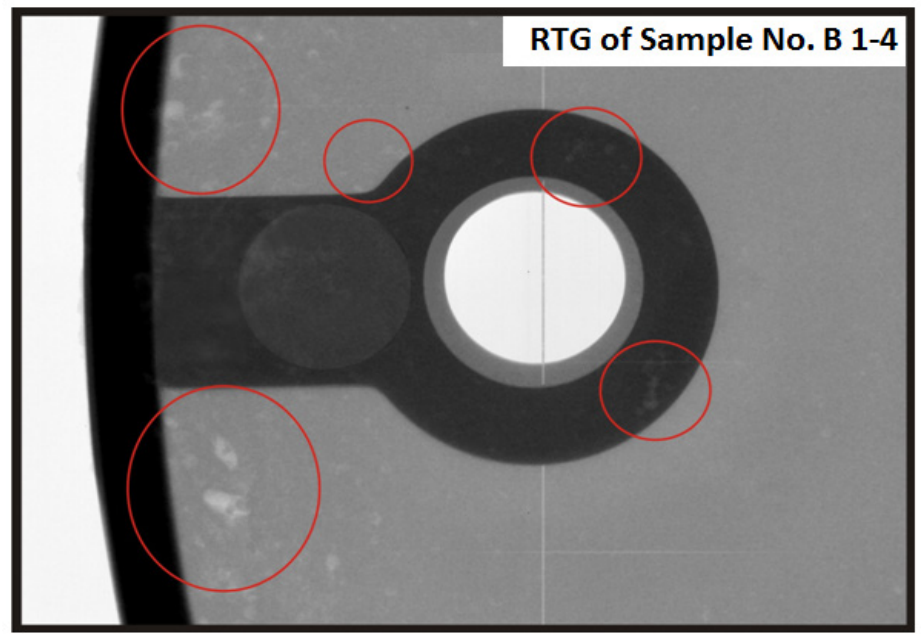

Fig. 5. RTG picture of sample No. B 1.4

\section{Achieved results}

The highest values of permanent deformation with regard to pressing speed have been recorded in analyzed samples at plunger pressing speed of 2,0 m.s. $\mathrm{s}^{-1}$. With further increase of the plunger speed up to the value of $2,8 \mathrm{~m} \times \mathrm{s}^{-1}$, decrease of the values of permanent deformation up to the value $s=0,033 \mathrm{~mm}$. At this pressing speed, i.e. $2,8 \mathrm{~m} \times \mathrm{s}^{-1}$ casts of the highest quality have been manufactured. Based on the course of permanent deformation in dependence on pressing speed it can be said that mold cavity filling depends on metal flow speed in an intake port, which determines the mold cavity filling regime. If we consider the effect of the specific pressure on the values of permanent deformation, from the obtained results it follows that the highest quality castings were made at the highest levels of specific pressure, i.e. $25 \mathrm{MPa}$, for which, as it follows from Figure. 3, the lowest values of permanent deformation were recorded. With the decreasing specific pressure, the mechanical properties deteriorate. Based on the measured values of the permanent deformation as well as RTG pictures it follows that considering the resulting quality of the analyzed castings, the plunger pressing speed, which determines the regime of the die cavity filling and specific pressure have a significant influence on the casting quality.

\section{Conclusions}

Based on the experimental analysis aimed at effect of the basic parameters of die casting (plunger pressing speed, specific pressure) on the values of the permanent deformation, the following conclusions have been made. The non-homogeneity of the die casting manifests itself primarily by the increased 
number of cavities in its individual parts. Sizes and distribution of cavities in the volume of the castings depend on the filling performance of the particular part of the die casting. Filling of the cavity is dependent on the speed of melt entry in the cavity ingate. The rate of entry in turn depends on the speed of pressing in the filling chamber of the machine. Thus we can conclude that the pressing speed is the basic technological parameter of the die casting time determining the filling of the cavity and thus directly affects the homogeneity of the casting. Another factor determining the filling regime that effects directly the quality of the die casting is the specific pressure. Nowadays, it has been the mostly discussed factor in die casting process. On the one hand, it has been confirmed that the increased values positively effect the tightness and uniformity of the die casting, on the other, they reduce the life of high pressure die casting machines. Die castings of the optimal quality can be produced only when the parameters are optimally set.

This article has been prepared within the project VEGA No.1/0041/16.

\section{References}

[1] Gaspar, S., Pasko, J. \& Malik, J. (2011). Inner quality of die castings made from silumin'at pressure die casting process. Manufacturing Technologies.16(3), 3-7.

[2] Malik, J., Eperjesi, L., Fecko, D. \& Gaspar, S. (2011). The influence of the tablet height and final pressure on the final quality of the casting. Archives of Foundry Engineering 11(1), 37-40.

[3] Podrocká, R, Malik, J. \& Bolibruchová, D. (2015). Defects in high pressure die casting process. Manufacturing Technologies. 15(4), 674-678.

[4] Białobrzeski, A. (1992). Pressure die casting. Machinery, equipment and technology. Warszawa WNT. (in Polish).

[5] Vinarcik, E., J. (2003). High Integrity Die Casting Processes. New York: John Wiley and Sons.

[6] Reikher, A. \& Barkhudarov, M. (2007). Casting an analytical approach, Springer Verlag.

[7] Orlowicz, A.W., Tupaj, M., Mroz, M. \& Trytek, A. (2015). Combusion engine cylinder liners made of Al-Si alloys. Archives foundry engineering. 15(2), 71-74.

[8] Tillova, E., Chalupova, M. \& Konecna, R. (2001). Structural study of silumin AlSi7MgTi. Acta Metallurgica Slovaca. 7, 456-458.

[9] Zyska, A., Konopka, Z. Lagievska, M. \& Nadolski, M. (2015). The Influence of Technological Parameters on the Properties of Castings Produced by the Vacuum Assisted Pressure Die Casting Method. Archives of Foundry Engineering. 15(1), 164-168.

[10] GME 60007, Aluminiumteile für Treibwerklagerung und Aluminiumnenkerne von Dämpfungsblocken, Conti Tech Vegum VC.

[11] GME 60156, Test Method for Determinig the Compression Properties of centre Tubes, Vauxhall Motors LTD, 2001. 